\title{
Knowledge Management and Value Creation: Evidence from Tunisian Companies
}

\author{
Sana Ouechtati (Corresponding author) \\ Dept. of Management, Faculty of Law, Economics and Management of Jendouba \\ University of Jendouba, Tunisia \\ E-mail: ouechtatisana05@gmail.com
}

Samir Mellouli

Dept. of Management, University of Manouba, Tunisia

Ecole Supérieur de Commerce de Tunis

E-mail: samirmellouli@yahoo.fr

Received: Feb. 6, 2018 Accepted: April 3, 2018 Published: April 16, 2018

doi:10.5296/bmh.v6i1.12621 URL: http://dx.doi.org/10.5296/bmh.v6i1.12621

\begin{abstract}
Knowledge management is considered as a way to well manage the intellectual capital of the company. The remarkable importance of knowledge management is reflected in the growing importance of its place in the world of economics. The objective of this paper is to study the impact of knowledge management on the different types of value creation such as economic, social, institutional and instrumental. To achieve this goal, we used a quantitative study of 35 Tunisian companies operating in different sectors. The empirical results of the exploratory analysis show that knowledge management has a significant impact on both economic value. On the contrary, it has a mixed impact on both social value.
\end{abstract}

Keywords: Knowledge management, Value creation, Economic value, Social value 


\section{Introduction}

In recent years, of severe environmental turbulence, businesses and organizations in general need to pay particular attention to the management strategies or processes most likely to ensure their success and help them achieve sustainable competitive advantages over time. However, knowledge management is a strategic tool for creating value in organizations (Zollo \& Winter, 2002), in that organizations are able to achieve the best allocation of external resources (Giuliani, 2007).

In line, KM becomes a key management capability to create value. Thus, the importance of this capacity entrenches the consideration of knowledge as a key strategic resource (Grant, 1996). Thus, if companies want to take advantage of the knowledge they possess, they need to know how knowledge is created, shared and used within the company.

The existing literature suggests that companies that apply $\mathrm{KM}$ processes are primarily seeking higher value creation. Nevertheless, the key is not its static analysis at any point in time; the recombination of processes should be recurrent and sustainable. According to Sirmon, Hitt, \& Ireland (2007), having very valuable or scarce resources and capabilities is not enough to gain competitive advantage or create value; Companies must also be able to manage them effectively. Therefore, value creation can also occur by recombining existing resources and capabilities (Sirmon, Hitt, \& Holcomb, 2007). Organizational capabilities need to be reconfigured to enable the company to create value over time.

Thus, the purpose of this study is to develop a model that provides a better understanding of how a company creates different values, through its knowledge management processes (KM). This research explores value creation through the KM process, and proposes that KM processes such as creation, capitalization and knowledge transfer themselves constitute a higher order capability that contributes to increasing the creation of economic and social value. On this basis, and building on the existing literature on the subject, this study aims to establish how companies can develop these KM processes, thus providing superior value.

To date, the link between KM and value creation has not been fully explored. Given the importance of KM for businesses, it becomes essential to know how KM affects value creation in Tunisian companies. The objective of this article is to analyze the impact of knowledge management on value creation in Tunisian companies and to measure the effects of $\mathrm{KM}$ on the creation of different value.

This paper proposes to answer the following question: what is the impact of knowledge management practices on value creation in the enterprise?

The answer to this question will be based primarily on the review of the specialized literature. At the end of this analysis, we arrive at our conceptual model that integrates the different knowledge management practices and value creation of the company. Thus, we present the effect of these different practices in the creation of value of the company. Then, we will try to validate our model in the context of the investigation. To do this, we will adopt a study based on the questionnaire distributed to different Tunisian companies. The investigative context is the Tunisian companies which are located in a changing and constantly changing market and 
which is moving more and more towards a knowledge-based economy. This research aims to document and bring a new validation of the theory of knowledge management, mainly as a source of value creation.

\section{Theoretical Background and Research Hypotheses}

\subsection{The Knowledge Management}

In an economy marked by the growth of information and communication technologies as well as the ever-increasing innovation, knowledge management is becoming the most important concern of any company (Masson, 1997).

The emergence of the theory of the firm or resource based-view (RBV) developed by Edith Penrose (1959) sees the company as a set of resources and places the creation of knowledge at the center of the growth process of the firm. As Ermine (2000) states: "Knowledge is now considered as a capital that has an economic value and a strategic status for the company, in the same way and often more than the tangible assets of this company".

However, Penrose has been involved extensively in the emergence of a new economic approach that places knowledge at the center of wealth creation processes. In the continuation of the theory of resources, comes the knowledge-based approach (KBV) which considers organizational knowledge as a strategic resource determining the competitive advantage of the company. Thus, this theory placed knowledge at the center of the process of creating competitive advantage and value creation (Dubois \& Dupuy, 2007). In the same line of idea, Nonaka (2000) describes: "in an economy where the only certainty is uncertainty; the only source of sustainable competitive advantage is knowledge".

Knowledge management is currently an expanding field, after peaking towards the end of the 1990s (Ermine, 2000). Indeed, knowledge management is an integrated approach today in most companies (Grundstein, 2002). For Ermine (2000) knoweledge management is therefore an extremely diversified problem, which affects practically all the fundamental aspects of the company. This is why it was considered as a new revolution of a magnitude comparable to the industrial revolution of the twentieth century.

\subsubsection{The Knowledge Management Processes}

Knowledge management intervenes to lead the knowledge and protect in order to enrich and fully utilize to develop the business situation. Thus, the organization must not only acquire and exploit new knowledge, but recategorize and recontextualize it to be available to others, or for future generations (Prax, 2000).

\section{Knowledge Creation:}

The creation of new knowledge is the main objective of all companies as a source of value creation. In the same vein, Ermine et al. (2012) reported that "the KM postulates that the production of knowledge implies the production of value".

\section{Knowledge Capitalization:}


For Grundstein (1991 cited by Grundstein, 2002) "capitalizing the knowledge of the company is to consider the knowledge used and produced by the company as a set of wealth constituting a capital and to derive interest from it, helping to increase value of this capital". Generally, the capitalization of knowledge is a process of codification, preservation and documentation of knowledge in order to protect and reuse in other activities.

\section{Knowledge transfer:}

Knowledge management capacity lies in the ability to disseminate this knowledge. Thus, for Ermine (2000): "to share: the corresponding slogan can be summarized by passing from the individual intelligence to the collective intelligence. It is the culmination of the observation that, currently, in managing the complexity of their process, companies can no longer be satisfied with the individual actions of the actors, but must integrate them into harmonious and creative collaborative projects".

The value creation is based on the appropriate combination of the human network, social capital, and intellectual capital and technology assets, through a culture of change. It is argued that effective organizations must not only negotiate their migration from knowledge sharing to a culture of knowledge creation, but also create sustained organizational and societal values. The latter is the foundation of the proposed concept of creating the value of knowledge and represents the main organizational and societal challenges facing modern organizations. It is therefore timely to measure the effect of knowledge management on value creation.

\subsection{The Value Creation}

Value creation is becoming a topic of current interest in various fields of management science (Cappelletti \& Khouatra, 2002). With the globalization and liberalization of the financial market, companies and especially the leaders who are always looking to create wealth for their shareholders are giving increasing importance to the concept of value creation. Value creation has been stoked for several years. This great importance has resulted in an abundance of publications in order to further clarify this concept. In this research, we try to study types of value creation such as: economic value and social value

The economic value is the product of implementing strategies that are concerned about cost reduction, better use of resources and especially investment in research and development to be innovative and differentiated from competitors. According to Khoutra (2005) the social value is defined as the satisfaction of the quality of life of the staff at work. Social value can also have an external dimension and then refers to the question of corporate social responsibility and the external social effects of its activities.

\subsection{The Contribution of Knowledge Management to the Value Creation}

The new economy has introduced a new lexicon in which knowledge capital, intellectual capital, learning organizations, intangible assets and human capital describe new forms of economic value (Bontis, 2001). For decades, the trend has shifted away from a product-based, asset-based economy to a knowledge economy based on intangible assets (Kaplan \& Norton, 
2004). This change means that the knowledge products and services component becomes an important strategic resource (Quinn, 1992). Thus, the only source of competitive advantage that can be harnessed is the ability to create, find and combine knowledge of new products and services faster than the competition (Davenport et al., 2000).

In this context, recent studies highlight the importance of knowledge management research as a source of value creation. The work of Cepeda-Carrion et al. (2017) contributed to the literature through the proposal of a model analyzing the possible combinations between critical knowledge management processes (absorption capacity, knowledge transfer and knowledge translation), which will result in the creation of a superior customer value. They have shown that the combination of processes leads to value for the customer. Thus, there is also, Campos-Climent et al. (2017), studied the relationship between the creation of knowledge absorption capacity and the creation of shared value in French and Spanish social enterprises, the authors propose a research model based on structural equations. His work has empirically tested the theoretical contribution of Porter \& Kramer (2011), which emphasizes the existence of a positive relationship between the creation of social value and the creation of economic value in organizations.

However, Seyedehfatemeh Golrizgashti (2016) studied the effects of applying knowledge management on value creation in the supply chain, an empirical study covering ten appliance manufacturers in Iran. Results reveal the positive effects of knowledge management on the Balanced Scorecard approach in manufacturing industries. Also, Edvardsson et al. (2011) analyzed the effect of knowledge management (KM) on value creation in Icelandic service firms and examined how KM contributes to value creation, and how to measure of which KM allocates intangible assets. The results of the study show that companies with KM report more value creation in the areas of customer capital, innovation and human capital compared to companies that did not introduce KM.

Among the authors interested in the issue of knowledge management and value creation is Gohary \& Hamzelu (2016), who have studied the impact of customer knowledge management on the creation of knowledge on the creation of value co-creation. They illustrated a conceptual framework of the customer knowledge management process.

Businesses using knowledge storage strategies tend to focus on reuse of knowledge to reduce costs and increase efficiency. These firms tend to focus on learning and reward the use of existing knowledge, which tends to be measured by the volume of data (Edvardsson, 2008). However, there are companies that use knowledge transfer strategy focus on creating new knowledge to increase innovation. They tend to focus on rewards to stimulate the development of new ideas. Thus, these strategies have potential implications for the creation of economic value: lowering costs, increasing efficiency, improving quality and innovation (Edvardsson, 2008).

In this context, KM is seen as a framework for designing an organization's goals, structures, and processes so that the organization can use what it can learn and create value for its customers and community (Choo, 1999). Hence the following assumptions are plotted: 
H1.1: Knowledge creation has a positive effect on the creation of economic value.

H1.2: knowledge capitalization has a positive effect on the creation of economic value.

H1.3: Knowledge transfer has a positive effect on the creation of economic value.

In terms of socio-technical design, KM tools to support social value aims to connect various social communities. Tools can promote social value by providing virtual spaces for interaction, providing context and history of interaction and providing a motivational element to encourage people to share their knowledge with each other (Huysman \& Wulf, 2006). Tsai $\&$ Ghoshal (1998) reveal an association between social capital and business value creation. This relationship is supported by related research (Nahapiet \& Ghoshal, 1998). In addition, in terms of organizational structure, social capital helps people develop trust, respect and understanding of others, especially in the context of a strong organizational bureaucratic culture. This indirectly contributes to the creation of social value. Intangible assets have the potential to create more value than physical or material assets. Three intangible factors, consisting of human capital, external capital and structural capital, are expected to generate future benefits and create sustained organizational and societal values (Allen, 2003; Blair \& Wallman, 2001). These also include business relationships, internal structure, human competence, social citizenship, environmental health, and corporate identity (Allen, 1999). Once created, the intangible and tangible value is included in the value networks to create relationships between individuals, groups or organizations and can hinder any sharing and knowledge creation activity and any the creation of social value.

From the previous development, we were able to put the following assumptions:

H2.1: Knowledge creation has a positive effect on the creation of social value.

H2.2: knowledge capitalization has a positive effect on the creation of social value.

H2.3: knowledge transfer has a positive effect on the creation of social value.

\section{Research Methodology}

\subsection{The Choice of Research Methodology}

We generally distinguish between two types of scientific methods namely, inductive methods and deductive methods. Given the causal explanatory nature of our problematic, we adopted a quantitative deductive methodology. Deductive methods start from a general theoretical corpus to go towards a particular domain of validation of hypotheses formulated a priori by the researcher (Raymond-Alain Thiétart, 2014).

\subsection{Questionnaire Survey}

To test the reliability of the measurement scales of the different variables and the assumptions presented above, we adopted a quantitative study. This study was conducted through a questionnaire. Our sample consists of 35 Tunisian companies. We limited our study to only 35 companies following refusals to answer our questionnaire. Our questionnaire is largely based on a survey conducted by Canadian Statistics (2001) to determine what extent 
knowledge management practices are or will be used by Canadian companies. The ultimate final of our questionnaire is to examine the association that can remain between knowledge management and value creation for Tunisian companies and to test the hypotheses formulated from the literature review. Our questionnaire is structured in five parts distributed as follows. The first part contains information on the signage of the Tunisian company surveyed. The second part aims at measuring the computer tool used by the company surveyed. The third part measures, through a likert scale, the perception of knowledge management (explanatory variables) in Tunisian companies. The fourth part measures on the basis of a likert scale the perception of the typology of the creation of value (variables to be explained) in the companies surveyed

\subsection{Variables Measurement (Note 1)}

In this study we used seven variables including three explanatory variables and four variables to explain the knowledge management effect on value creation in Tunisian firms. Thus these variables are measured by a certain number of predestined items through their relevance according to the trend of the study. Our questionnaire behaves of four main parts; the questions asked are mainly closed questions in order to take the most specified information.

\subsubsection{Measure of Knowledge Creation}

The variable knowledge creation is proxied by five items. Variables proposed to measure this concept include: Assignment of resources to research and acquisition of external knowledge, Assignment of resources to dissemination and sharing of knowledge among members of the organization, take charge of new development ideas and new products, offer outside training to workers so that they can maintain their skills, use partnerships or strategic alliances to acquire knowledge, there is investment in new technology. The assessment is made by the Likert scale at 5 points (from (1) rarely to (5) always).

\subsubsection{Measure of Knowledge Capitalization}

The knowledge capitalization variable is evaluated by four items. The variables proposed to measure this concept include: there is investment in the new technology, you make use of the various types of software at the level of the NICTs, there is memorization of the knowledge and expertise, and there is explicitness of the tacit knowledge (no written). The respondent will express the degree of influence of capitalization of knowledge in society. The assessment is made by the Likert scale at 5 points (from (1) rarely to (5) always).

\subsubsection{Measure of Knowledge Transfer}

The variable "knowledge transfer" is evaluated by two items. Proposed variables to measure this concept include: regular updating of databases including proven working practices, lessons learned and lists of experts, regular organization of information meetings to inform staff of new developments knowledge and knowledge. The respondent will express the degree of influence of capitalization of knowledge in society. The assessment is made by the Likert scale at 5 points (from (1) rarely to (5) always). 


\subsubsection{Measure of the Creation of Economic Value}

The creation of economic value is a dependent variable measured by a seven-point Likert scale ranging from from (1) rarely to (5) always 1 . This variable was measured by ten items. The variable is measured by a multi-item scale adopted from previous work. Variables proposed to measure this concept include: maximize the return on capital, improve the net operating margin rate (reduction of the cost of production, flexibility, efficiency), maximize Customer Satisfaction, maximize Employee Compensation, ensure Sustainability of Sales, and maximize Wealth Creation, Improve Economic Responsibility. These items are inspired by the work of Porter \& Kramer (2006 and 2011), Manea \& Pearce (2006), Lingyee \& Ogunmokun (2001).

\subsubsection{Measure of the Creation of Social Value}

To measure the creation of social value, we proposed a measure that combines elements related to the well-being of employees (Spear et al., 2009) and elements related to the preservation of the environment (Carayannis et al., 2014). This variable was measured by five items. The variable is measured by a multi-item scale adopted from previous work. Variables proposed to measure this concept include: Improving Legal Responsibility (respecting laws and regulations), Improving Ethical Responsibility (following social norms), Improving discretionary responsibility (philanthropic activities), Pride in belonging to a viable and liveable entity, Environmental and health security. These items are inspired by the work of Paters (2003), Somers (2005), Darby \& Jenkins (2006). This variable is measured by a five-point Likert scale ranging from from (1) rarely to (5) always 1.

\section{Results and Discussions}

\subsection{Purification and Reliability of Measurements}

To measure the reliability of the measurements, we conducted exploratory principal component analyzes (PCA). The reliability of a scale appreciates how well each item reflects the construct that it is supposed to measure (Igalens \& Roussel, 1998). Thus, the internal consistency of a scale of measurement is appreciated by the Cronbach Alpha coefficient. The reliability of a measurement scale is then verified as soon as the Cronbach Alpha coefficient is greater than 0.7 .

From Table 1 it can be seen that the items are strongly correlated with each other. Thus, the items participate in the formation of a single factor. In addition, the items are strongly correlated with the factor (all greater than 0.6). However, the Cronbach alpha values of all dimensions as well as those of each factor are satisfactory $(>0.7)$. 


\section{Macrothink}

Table 1. Cronbach Alpha measurements of each measure

\begin{tabular}{|l|l|}
\hline the variables & Cronbach Alpha \\
\hline Knowledge Creation & 0,824 \\
\hline Knowledge Capitalization & 0,812 \\
\hline The creation of economic value & 0,707 \\
\hline The creation of social value & 0,777 \\
\hline
\end{tabular}

\subsection{The Hypothesis Test}

\subsubsection{The Effects on the Creation of Economic Value}

Based on Fisher's test, the model of the impact of knowledge creation on economic value is statistically significant. It restores $19.9 \%$ of the variance of the variable to explain. In addition, the regression coefficient of the knowledge creation variable is statistically significant. Thus, these results verify and confirm hypothesis H1.1. Indeed, the variable creation of knowledge contributes in the explanation of the variable creation of economic value.

As for the impact of knowledge capitalization, Fisher's test statistics indicate that the model is statistically significant. It restores $8.6 \%$ of the variance of the variable to be explained. In addition, the regression coefficient for the knowledge capitalization variable is statistically significant. Thus, these results verify and confirm hypothesis H1.2. In fact, the variable knowledge capitalization contributes to the explanation of the variable creation of economic value.

With regard to the effect of knowledge transfer on economic value creation, Fisher's test statistics indicate that the model is statistically significant. It restores $10.7 \%$ of the variance of the variable to explain. In addition, the regression coefficient of the knowledge transfer variable is statistically significant. Thus, these results verify and confirm hypothesis H1.3. Indeed, the variable "knowledge transfer" contributes to the explanation of the variable creation of economic value.

\subsubsection{Effects on the Creation of Social Value}

Based on Fisher's test values of the impact of knowledge creation on value creation, the model is statistically significant. It restores $16.6 \%$ of the variance of the variable to explain. In addition, the regression coefficient of the knowledge creation variable is statistically significant. Thus, these results verify and confirm hypothesis H2.1. Indeed, the variable knowledge creation contributes in the explanation of the variable creation of social value.

Regarding the impact of knowledge capitalization, the model is insignificant on the basis of Fisher's test. As a result, the knowledge capitalization variable does not contribute to the explanation of the social value creation variable. These results lead us to reject hypothesis $\mathrm{H} 2.2$.

Fisher's test of the effects of knowledge transfer on value creation indicates that the model is 
statistically significant. It restores $21.8 \%$ of the variance of the variable to explain. In addition, the regression coefficient of the knowledge transfer variable is statistically significant. Thus, these results verify and confirm hypothesis H2.3. Indeed, the variable knowledge transfer contributes to the explanation of the variable creation of social value.

Table 2. Fisher test results in (\%), (the significance of the models)

\begin{tabular}{|l|l|l|l|l|l|l|l|}
\hline & \multicolumn{3}{c|}{ VE } & \multicolumn{1}{c|}{ VS } \\
\hline & $(1)$ & $(2)$ & $(3)$ & $(1)$ & $(2)$ & $(3)$ & $(1)$ \\
\hline R2 & 19.9 & 8.6 & 10.7 & 16.6 & 4.8 & 21.8 & 2 \\
\hline R2 Ajusté & 17.5 & 5.9 & 8 & 14.1 & 2 & 19.4 & $(0.9)$ \\
\hline
\end{tabular}

Note. With; VE: Economic Value, VS: Social Value. (1): knowledge creation. (2): knowledge capitalization. (3): knowledge transfer.

The results obtained from the linear regressions can be summarized in the following table 3:

Table 3. Summary of model significance

\begin{tabular}{|c|c|c|c|}
\hline \multicolumn{2}{|c|}{ Impact of knowledge management on value creation } & \multicolumn{2}{|c|}{ value creation } \\
\hline & & VE & VS \\
\hline \multirow[t]{3}{*}{ knowledge management } & knowledge creation & significant & significant \\
\hline & knowledge capitalization & significant & Not significant \\
\hline & knowledge transfer & significant & significant \\
\hline
\end{tabular}

Note. Where; VE: Economic Value, VS: Social Value.

\subsection{Discussions}

This statistical analysis of the data firstly makes it possible to describe the sample of our study using a uni-varied analysis (flat sorting) namely 35 companies, most of which are small businesses (20 to 49 employees) which are predominantly in the service sector. In a second place we will focus on the verification of the overall significance of the hypotheses based on a linear regression method. However, this analysis makes it possible to study in depth the impact of knowledge management practices on the typologies of value creation. In this perspective, it can be argued that knowledge management practices have, on the one hand, a definite impact on the creation of economic value, on the other hand, a mitigated impact on the creation of social. The results are shown in Table 4 below: 
Table 4. Result of the regression

\begin{tabular}{|l|l|l|}
\hline Impact of KM & VE & VS \\
\hline Knowledge creation & 0,446 & 0,408 \\
\hline & $(2,862)^{* * *}$ & $(2,564)^{* *}$ \\
\hline Knowledge capitalization & 0,294 & 0,22 \\
\hline & $(1,786)^{*}$ & $(1,279)$ \\
\hline Knowledge transfer & 0,327 & 0,467 \\
\hline & $(1,986)^{*}$ & $(3,032)^{* * *}$ \\
\hline
\end{tabular}

Note. ${ }^{*}, * *$ and $* * *$ indicate significance level respectively at $10 \%, 5 \%$ and $1 \%$; with; VE: Economic Value, VS: Social Value.

From Table 4, it appears that knowledge creation; knowledge capitalization and knowledge transfer positively and significantly influence the creation of economic value.

The first three sub-hypotheses concerning knowledge creation, knowledge capitalization and knowledge transfer and its impact on the creation of economic value are validated. The different interactions between the components of knowledge management and the creation of economic value are verified: knowledge creation / economic value, knowledge capitalization / economic value, knowledge transfer / economic value. These results are consistent with those of several authors who have tested these relationships such as (Cappelletti \& Khouatra, 2002, 2004; Davenport \& Prusak, 1998). Consequently the hypotheses H1.1, H1.2, H1.3 are validated.

Regarding the impact of independent variables the creation of social value, the results presented in Table 4 above have shown that knowledge creation and knowledge transfer positively influence the creation of social value.

With regard to the impact of independent variables on the creation of social value, the results presented in Table 4 above have shown that knowledge creation and knowledge transfer positively influence the creation of social value. At the end of these results the hypotheses H2.1, H2.3 is validated. These results are consistent with those of several authors who have tested these relationships such as (Cappelletti \& Khouatra, 2002, 2004).

Indeed, the financing of different forms of intangible at the level of the company only enhances the effect of the different components of knowledge management on the creation of social value. The more we invest in knowledge, the more social value develops.

Based on these results the hypotheses $\mathrm{H} 2.1, \mathrm{H} 2.3$ are validated. On the other hand, there is no relationship between the knowledge capitalization and the creation of social value, which leads to reject hypothesis H2.2.

Based on the results of this paper, in the Tunisian context, companies do not grant great importance on knowledge management practices. This is explained by several reasons. Firstly, the majority of Tunisian companies do not have a specific department dedicated to research and development. Secondly, there is a lack of investment in TIC. 
As result, there is a difficulty to change and innovate methods in the management practices of the company, the organization of work or external relations namely: to make cooperation or alliance strategies, tools, processes organizational and managerial techniques to enhance value creation.

\section{Conclusion}

This study analyzes the relationship between knowledge management practices and different types of value creation. A number of articles have been published on knowledge management and organizational value, but few have focused on institutional value and instrumental value. So our study fills this gap.

The paper focuses on a discussion of KM (knowledge creation and knowledge capitalization and knowledge transfer) based on a review and synthesis of a wide range of relevant publications. The definition of KM has evolved over the years. The purpose of this paper is to answer the following question: What is the impact of knowledge management practices on the creation of value in the company? In other words, we have studied the potential interactions between knowledge management and value creation in the enterprise.

We presented a review of the literature on the two variables of this research: knowledge management and value creation. Indeed, we have tried to study the main axes expressing these two concepts of research. Thus, at the end of this section we have developed a research model accompanied by twelve research hypotheses. Then, we presented in a first step the empirical approach that we implemented and then in a second step we preceded to the interpretation of the results to test our hypotheses. This study was conducted on a sample of 35 Tunisian companies operating in different sectors observed during 2016.

The empirical findings of this study have shown that knowledge management has a definite impact on both the creation of economic value. On the contrary, it has a mixed impact on both the creation of social value. Thus, apart from the case of a single unconfirmed hypothesis, all other hypotheses (five in number) are confirmed. We can then argue that knowledge management has a definite impact on value creation in the enterprise. This allowed us to confirm the hypotheses H1.1, H1.2, H1.3, H2.1, H2.3, and to reject hypotheses $\mathrm{H} 2.2$.

This study is likely to contribute to the existing literature. Result of this study could lead business strategists to become aware of the challenge of a new management practice in general and joint management of knowledge and innovation in particular. This latter was considered as a major competitive asset, the new wealth of the organization and stimulates these managers to devote more time and resources to knowledge management and open innovation management practices in order improve the competitive position of their companies.

Despite the contributions mentioned above, our work has, like any research a certain number of limits such as the generalization of results or the elaboration of standards, even if our sample is made up only of 35 companies, this is still insufficient to generalize the conclusions drawn from this research work. 


\section{Al Macrothink}

Business and Management Horizons

ISSN 2326-0297

2018, Vol. 6, No. 1

Future perspectives of our research can be considered. They concern both theoretical deepening and methodological improvements. It would consist in deepening and enriching the different scales of measurement of our model in order to check the multi-dimensionality of all the components of knowledge management. Also, variable selection and measurement will be further developed in future work. Thus, the sample of our study is heterogeneous; it would be interesting to test our model in specific sectors of activity especially for companies that rely primarily on the knowledge and knowledge of their employees.

\section{References}

Aktouf, A. (1987). Méthodologie des sciences sociales et approche qualitative des orqanisation.une introduction à la démarche classique et une critique (p. 213). Montréal: les presses de l'université de Québec.

Alavi, M., \& Leidner, D. (2001). Review: Knowledge management and knowledge management systems: Conceptual foundations and research issues. MIS Quarterly, 25(1), 107-136. https://doi.org/10.2307/3250961

Ali, G., \& Bahman, H. (2016). Modeling customer knowledge management to make value co-creation. Business Information Review, 33(1), 19-27. https://doi.org/10.1177/0266382116631850

Allen, V. (1999). The art and practice of being a revolutionary. Journal of Knowledge Management, 3(2), 121-132. https://doi.org/10.1108/13673279910275576

Allen, V. (2003). The Future of Knowledge Increasing Prosperity through Value Networks. Butterworth- Heinemann.

Annie, C. L. (2002). défis liées à l'insertion des technologies de l'information et de communication dans les économies africains. Ajustement et technologie en Afrique (p. 103).

Bayed, M. et al. (2002). Gestion des compétences et knoweledge management : renouveau de la création de valeur en gestion des ressources humaines (p. 5). Edition liaisons. https://doi.org/10.3917/riges.273.0100

Blair, M. M., \& Wallman, S. M. H. (2001). Unseen Wealth: Report of the Broolings Task Force on Intangibles. Washington: Brookings Institution Press.

Bontis, N., Dragonetti, N., Jacobsen, K., \& Roos, G. (1999). The knowledge toolbox: A review of the tools available to measure and manage intangible resources. European Management Journal, 17(4), 391-402. https://oi.org/10.1016/S0263-2373(99)00019-5

Campos-Climent, V., \& Sanchis-Palacio, J. R. (2017). The influence of Knowledge Absorptive Capacity on Shared Value Creation in Social Enterprises. Journal of KnowledgeManagement. https://doi.org/10.1108/JKM-02-2017-0084

Cappellati, L., \& et Khouatra, D. (2002). la mesure de la création de valeur organisationnelle: le cas d'une entreprise du secteur de la gestion de patrimoine.

Cepeda-Carrion, I. et al. (2017). Critical processes of knowledge management: An approach 
toward the creation of customer value. European Research on Management and Business Economics, 23, 1-7. https://doi.org/10.1016/j.iedeen.2016.03.001

Choo, C. W. (1999). The art of scanning the environment. ASIS Bulletin Pre-print. [Online] Available: http://www.choo.fis.utoronto.ca/FIS/ResPub/ASISbulletin/default.html

Davenport, T., \& Prusak, L. (1998). Working Knowledge: How Organizations Manage What They Know. Boston: Harvard Business School Press.

Dubois, P., \& Dupuy, Y. (2007). Connaissance du management. Ed Economica

Edvardsson, I. R. (2008). HRM and knowledge management. Employee Relations, 30(5), 553-561. https://doi.org/10.1108/13683041111184062

Ermine, J. L. (2000). les systèmes de connaissances (2nd éd.). éd Hermes.

Ermine, J. L., Moradi, M., \& Brunel, S. (2012). une chaine de valeur de la connaissance. Revue de management international (pp. 29-40).

Giuliani, E. (2007). Networks and heterogeneous performance or cluster firms. In K. Frenken (Ed.), Applied Evolutionary Economics and Economic Geography, Cheltenham, Edward Elgar (pp. 161-179).

Golrizgashti, S. (2016). Effect of knowledge management on supply chain value, empirical evidence from Iran. Int. J. Business Performance and Supply Chain Modelling, 8.

Grant, R. M. (1996). Prospering in dynamically-competitive environments: organizational capability as knowledge integration. Organization Science, 7(4), 375-387.

Grundstein, M. (2002). le management des connaissances dans l'entreprise: problématiques, axe de progrès, orientation. Research Report juillet.

Grundstein, M., \& GAMTH. (2002). un cadre directeur pour repérer les connaissances cruciales pour l'entreprise. MG Conseil février.

Hansen et al. (1999). les meilleurs articles de la HBR sur le management du savoir en pratique. Ed organisation 2003 (pp. 119-148).

Huysman, M., \& Wulf, V. (2006). IT to support knowledge sharing in communities, towards a social capital analysis. Journal of Information Technology, 21, 40-51. https://doi.org/10.1057/palgrave.jit.2000053

Ingi Runar Edvardsson Gudmundur Kristjan Oskarsson. (2011). Knowledge management and value creation in service firms. Measuring Business Excellence, 15(4), 7-15.

Lordon, F. (2000). la création de valeur comme rhétorique et comme pratique. Généalogie et sociologie de la valeur actionnariale.

Masson, B. (1997). La gestion de la connaissance au secours de la compétitivité. La Revue des Sciences de Gestion, Direction et Gestion des Entreprises, 164-165, 47. https://doi.org/10.1051/larsg:1997017 


\section{Macrothink}

Business and Management Horizons

ISSN 2326-0297

2018, Vol. 6, No. 1

Mellouli, S. (2007). Problématique de survie de l'entreprise artisanale. Thèse de Doctorat d'Etat, Faculté des Sciences Economiques et de Gestion de Tunis (p. 136).

Mezzourh, S., \& Nakara, W. (2009). l'innovation dans l'espace de connaissance. ASAC2009; institut d'administration des entreprises de Toulouse.

Mohammadreza, M., Sherry, R., Gina, H., \& Windsor, J. (2015). Knowledge Management and the Creation of Business Value. Journal of Computer, 2, 97-129. https://doi.org/10.1080/08874417.2015.11645785

Nahapiet, J., \& Ghoshal, S. (1998). Social capital, intellectual capital, and the organizational advantage. Academy of Management Review, 23(2), 242-266. https://doi.org/10.2307/259373 https://doi.org/10.5465/AMR.1998.533225

Nonaka, I., \& Takeuchi, H. (1995). The Knowledge-Creating Company: How Japanese Companies Create the Dynamics of Innovation. Oxford: Oxford University Press.

Penrose, E. T. (1959). The Theory of the Growth of the Firm. New York: John Wiley.

Prax, J. Y. (2000). le guide du knoweledge management. Ed Dunod Paris.

Preiss, K., Goldman, S. L., \& Nagel, R. N. (1996). Cooperate to Compete: Building Agile Business Relationships. Van Nostrand Reinhold.

Raymond-Alain, T. (2014). Méthodes de recherche en management-4ème édition Dunod.

Sirmon, D. G., Hitt, M. A., \& Ireland, R. D. (2007). Managing firm resources in dynamic environments to create value: Looking inside the black box. Academy of Management Review, $32(1), 273-292$.

Sveiby, K. E. (2000). Knoweledge management: la nouvelle richesse des entreprises savoir tirer profit des actifs immatériels de sa société. Ed Maxima; Paris.

Teece, D. (1998). Capturing value from knowledge assets: The new economy, markets for know-how, and intangible assets. California Management Review, 40(3), 55-79. https://doi.org/10.2307/41165943

Tsai, W., \& Ghoshal, S. (1998). Social capital and value creation: The role of intrafirm networks. Academy of Management Journal, 41(4), 464-476. https://doi.org/10.2307/257085

Uden et al. (2013). The Role of Knowledge in the Value Creation Process and Its Impact on Marketing Strategy, 7th International Conference on KMO, AISC 172 (pp. 589-600).

Vanessa, C. C., \& Joan, R. S. P. (2017). The influence of Knowledge Absorptive Capacity on Shared Value Creation in Social Enterprises. Journal of Knowledge Management. https://doi.org/10.1108/JKM-02-2017-0084

Zollo, M., \& Winter, S. G. (2002). Deliberate learning and the evolution of dynamic capabilities. Organization Science, 13(3), 339-351. 
Note

Note 1. Items used to measure knowledge creation; knowledge capitalization and knowledge transfer were largely based on a survey conducted by Canadian Statistics Canada (2001) to determine what extent knowledge management practices are or will be used by Canadian firms.

\section{Copyright Disclaimer}

Copyright for this article is retained by the author(s), with first publication rights granted to the journal.

This is an open-access article distributed under the terms and conditions of the Creative Commons Attribution license (http://creativecommons.org/licenses/by/3.0/). 